Makale Geliş | Received: 16.09.2019

Makale Kabul | Accepted: 08.10.2019

DOI: $10.18795 /$ gumusmaviatlas.620704

Mavi Atlas, 7(2)/2019: 220-242

Araştırma Makalesi | Research Article

Mustafa Nuri URAL

Dr. Öğr. Üyesi | Assist. Prof. Dr. Gümüşhane Üniversitesi, Mühendislik ve Doğa Bilimleri Fakültesi, Gümüşhane-TÜRKIYE Gumushane University, Faculty of Engineering and Natural Sciences, Gumushane-TURKEY

ORCID ID: 0000-0001-7011-401X

mnu23@yahoo.com

Özlem TUNA

Dr. Öğr. Görevlisi | Lecturer Dr. Afyonkarahisar Sağlık Bilimleri Üniversitesi, Sağlık Bilimleri Fakültesi, Afyonkarahisar-TÜRKIYYE Afyonkarahisar University of Health Sciences, Faculty of Health Sciences, Afyonkarahisar-TURKEY

ORCID ID: 0000-0002-5842-7889

ozltuna@hotmail.com

\title{
Kurumsal Sürdürülebilirliğin Dünyanın En Çok Konuşulan Dillerinde Çevrimiçi Görsel Algısı
}

\section{$\ddot{O} z$}

Birçok kullanıcı dostu özelliğe sahip olan internet, farklı kültürlerden insanların görsel verilere daha kolay erişmesini ve paylaşmasını sağlamaktadır. Bu çalışmada "kurumsal sürdürülebilirlik” kavramının dünyanın en çok konuşulan dillerinde nasıl algılandığını keşfetmeye yönelik bir girişimde bulunulmuştur. Bu amaçla, dünyanın en çok konuşulan 12 dili tespit edilmiştir: Çince, İngilizce, İspanyolca, Almanca, Fransızca, Türkçe, Urduca, Arapça, Bengalce, Portekizce, Rusça ve Japonca. Ardından, "kurumsal sürdürülebilirlik" terimi her birine çevrilmiştir. Daha sonra, her çeviri images.google.com.tr adresinde görsel aramada kullanılmıştır. Her dildeki ilk 50 sonuç analiz edilmiş ve temalar halinde sınıflandırılmıştır. Sonuçlar, algıların dile ve kültüre bağlı olarak değiştiğini göstermiştir. Algılar, bazı dillerde çevre yönetimi ve ekosistemin korunması ile ilgili görseller üzerinden çevresel yönü; diğerlerinde ise insan ve toplum görselleri üzerinden sosyal yönü vurgulamıştır.

Anahtar Kelimeler: Kurumsal Sürdürülebilirlik, Kültürel Farklar, Görsel Alg1, Resim, Görsel İçerik Analizi.

\section{Online Visual Perception of "Corporate Sustainability" in the World's Most Spoken Languages}

\begin{abstract}
The internet with many user-friendly features lets people from different cultures access and share visual data more easily. Intrigued by this opportunity, an attempt was made in this study to explore how the concept of "corporate sustainability" was perceived in the most spoken languages of the world. To that end, the top 12 languages of the world were identified - Chinese (Mandarin), English, Spanish, German, French, Turkish, Urdu, Arabic, Bengali, Portuguese, Russian and Japanese. Then, the term "corporate sustainability" was translated to each. Next, an image search was performed using each translation result as a keyword on images.google.com. The first 50 results in each language were analyzed and categorized into themes. Results showed that perceptions varied depending on the language and culture. Perceptions highlighted the environmental aspect in some languages, with images about environmental management and preservation of the ecosystem, and the social aspect in others, with visuals of humans and society.
\end{abstract}

Keywords: Corporate Sustainability, Cultural Differences, Visual Perception, Image, Visual Content Analysis. 


\section{Giriş}

\subsection{Kurumsal Sürdürülebilirliğin Kavramsal Çerçevesi}

1960 ve 1970’li yıllarda işletmelerin temel önceliğinin kâr maksimizasyonunu olduğu görülürken, 90’lı yılların sonunda ekonomik kârlılığın dışında sorun yaratan diğer kriterler ile de ilgilenilmeye başlanmıştır. Günümüzde ise işletmelerden kâr etmelerinin yanında çevresel ve sosyal sorumluluklarını yerine getirmeleri de beklenmektedir (Schaltegger, Windolph, Harms ve Hörisch 2014: 4).

1960’lardan bugüne kurumsal sürdürülebilirliğin, literatürde farklı bakış açılarıyla değerlendirildiği görülmektedir. Geçen birkaç on yılda birçok bilim adamı sosyal, çevresel ve ekonomik performans arasındaki ilişki üzerine teorik bir çerçeve sunmuş (Figge ve Hahn 2012; Ganescu 2012; Zhang vd. 2013), bu doğrultuda bazı yazarlar sosyal ve ekonomik performans arasındaki ilişkiye odaklanmış (Bansal 2005; Schaltegger, Herzig, Kleiber ve Müller 2002; Shrivastava ve Hart 1995), diğerleri ise çevresel ve ekonomik performans arasındaki ilişki ile ilgilenmişlerdir (Lee ve Ball 2003; MolinaAzorín, Claver-Cortés, López-Gamero ve Tarí 2009; Sharma ve Ruud 2003; Wagner ve Schaltegger 2004). Bu çalışmaların yanında pek çok yazar kurumsal sürdürülebilirliğin üç boyutunu bir arada ele alan bütüncül yaklaşımı benimsemişlerdir (Bansal 2005; Benn, Dunphy ve Griffiths 2006; Dyllick ve Hockerts 2002).

$\mathrm{Bu}$ çalışmada kurumsal sürdürülebilirlik, bütüncül yaklaşımla ele alınmış ve konuya literatürdeki diğer çalışmalardan farklı bir bakış açısıyla yaklaşılmıştır. Kurumsal sürdürülebilirlik kavramının literatüre dayalı olarak değil, internette yer alan görsellere bağlı olarak nasıl algılandığı belirlenmeye çalışılmıştır. Değişik dillerde ve dolayısıyla bu dillerin kullanıldığı kültürlerde "kurumsal sürdürülebilirlik" kavramına yönelik farklı algıların bu dillerde yapılan görsel tarama sonuçlarına dayanılarak gerçekleştirilmesi, çalışmanın özgünlüğünü ortaya koymaktadır.

\subsection{Amaç}

İnsanlar ilk çağlardan beri düşüncelerini daha kalıcı olan yazı, resim, şekil ve çizimlerle ifade etmişlerdir. Düşüncenin görselleştirilmesi aşamasında kullanılan imgeler, kavramların nasıl algılandıkları ile ilgili önemli ipuçları vermektedir. Bu gerçeklikten hareketle, çalışmanın temel amacı, "kurumsal sürdürülebilirlik" kavramının günümüzün en önemli iletişim ortamlarından biri olan internette farklı dillerde ne şekilde algılandığı ve bu algının dillere göre değişiklik gösterip göstermediğinin belirlenmesidir.

$\mathrm{Bu}$ temel amaç doğrultusunda aşağıdaki soruların cevabı aranmıştır: 
• "Kurumsal sürdürülebilirlik" kavramı dünyanın en çok konuşulan dillerinde internet ortamında hangi görsel bileşenler kullanılarak ifade edilmiştir?

- Kullanılan görsel bileşenler dillere göre farkl1lık göstermekte midir?

- Kullanılan görseller hangi temalar altında gruplanabilir?

\section{Yöntem}

$\mathrm{Bu}$ çalışmayla özellikle son 30 yıldır popülerlik kazanmış olan "kurumsal sürdürülebilirlik" kavramının farklı dillerde görsel olarak nasıl algılandığının belirlenmesi amaçlanmıştır.

Çalışmada öncelikle kurumsal sürdürülebilirlik kavramının analizi yapılmış ve literatürde konu ile ilgili yardımcı kavramlar incelenmiş ve daha sonra araştırmada başvurulacak diller belirlenmiştir.

Tablo 1. Dünyada en çok konuşulan diller (Ethnologue, 2016) ve bu dillerdeki "kurumsal sürdürülebilirlik" kavramının karşılığ1

\begin{tabular}{|c|c|c|c|}
\hline No & Dil & Çeviri & Kişi Sayısı* \\
\hline 1 & Çince (Mandarin) & 企业可持续发展 & 840 \\
\hline 2 & İspanyolca & sostenibilidad corporativa & 350 \\
\hline 3 & İngilizce & corporate sustainability & 340 \\
\hline 4 & Arapça & الاستدامتللثركات & 220 \\
\hline 5 & Urduca & كاريوريظٍِائبدارى & 200 \\
\hline 6 & Bengalce & কর্পোরেটসাস্টেনিবিলিটি & 180 \\
\hline 7 & Portekizce & sustentabilidade corporativa & 170 \\
\hline 8 & Rusça & корпоративной устойчивости & 160 \\
\hline 9 & Fransizca & la durabilité d'entreprise & 130 \\
\hline 10 & Japonca & 企業の持続可能性 & 125 \\
\hline 11 & Almanca & unternehmens nachhaltigkeit & 100 \\
\hline
\end{tabular}

* İlgili dili kullanan yaklaşık sayı (milyon kişi)

Dünyada en çok konuşulan dillerin belirlenmesine yönelik çeşitli kriterler söz konusudur (Austin 2006; Weber 1997). Bu kriterlerle belirlenen sayılardaki değişiklik yalnızca demografik değerlerin sürekli değişiyor olmasından kaynaklanmaz. Burada en belirleyici unsurlardan biri dili yalnızca anadil olarak konuşanların mı yoksa yabancı dil (ikinci dil) olarak konuşanların da $\mathrm{m} ı$ hesaba katılacağıdır. Ayrıca dillerin lehçelerinin dikkate alınıp alınmaması da farklı listelerde dili konuşan sayısını etkileyebilmektedir. Bu çalışmada internet taraması yapmak için özellikle dünyada en çok konuşulan diller tercih edilmiştir. Böylece dünya üzerinde yaşayan tüm insan nüfusunun mümkün olduğunca büyük bir bölümünün görüşlerinin değerlendirmeye dâhil edilmesi amaçlanmıştır. Bu nedenle dili konuşan kişi sayısından daha çok bu dilin en çok 
konuşulan diller içerisinde yer alıp almadığı göz önünde bulundurulmuştur. Bu amaçla seçilen 11 dil, Tablo 1'de verilmiştir. Tabloda yer alan bu diller birçok kaynakta dünyada en çok konuşulan diller arasında zikredilmektedir. Ayrıca, dünya üzerindeki durumun ulusal durum ile karşılaştırılabilmesi için Türkçe de çalışmaya dâhil edilmiştir. Türkçe dünya üzerinde yaygın olarak kullanılan bir dil olmasına rağmen bazı kaynaklar Azerice, Kırgızca, Türkmence vb. dilleri dâhil etmeyip yalnızca Türkiye Türkçesi’ni temel aldıkları için 70-80 milyon konuşan olduğu kabul edilmekte ve Türkçeyi dünyada en çok konuşulan diller arasında saymamaktadırlar. Kısaca bu çalışmaya Türkçe'nin dâhil edilmesinin asıl amacı en çok konuşulan dillerden biri olarak kabul edilmesi değil, araştırmacıların kendi ülkelerindeki durumu dünya geneli ile kıyaslamak istemelerindendir.

Sıralanan bu gerekçelerle öncelikle "kurumsal sürdürülebilirlik" kavramı belirlenen bu 11 dile Google Translate (Google Çeviri) ve dil uzmanları yardımı ile çevrilmiştir. Türkçe de dâhil edildiğinde bu çalışma toplam 12 dil ile sınırlıdır. Sonrasında resimlerin elde edilmesi için images.google.com adresinde bulunan Google görsel arama motorundan faydalanılmıştır. Şekil 1 arama sonuçlarına dair örnek bir ekran alıntısını sunmaktadır. Resimlerin elde edilmesi Ocak ayının ikinci haftasında (11-15 Ocak 2016) tarihleri arasında gerçekleştirilmiş ve her dilde çıkan ilk 50 resim kaydedilmiştir. Google arama sonuçları arama yapılan terim ile ne kadar ilgili oldukları ve arama sayfaların ne kadar önemli olduğuna bağlı olarak belli bir puanlamaya tabi tutmaktadır. Bu teknoloji Google tarafından geliştirilmiş ve "sayfa sıralaması" olarak adlandırılmıştır ve Google'da yapılan her türlü arama için otomatik olarak gerçekleşmektedir. Google'da bir terim arandığında sonuçlar bu sayfa sıralaması puanına göre sıralanmaktadır. Arama sonuçları en yüksek puanlı sayfadan en düşük puanlı sayfaya doğru sıralı olarak sunulmakta ve listelenen en üstteki resimler seçildiğinde, en iyi puanlama sonuçları da otomatikman seçilmiş olmaktadır.

Bu çalışmada ilk elli resim tercih edilmiş böylece Google tarafından en yüksek puan alan sayfalar kullanılarak çalışmanın kalitesi artırılmaya çalışılmıştır. Çalışmanın analiz aşamasında 12 dilde toplam 600 resim kullanılmıştır.

Veriler bir elektronik tablo programına girilmiştir. Yine analiz aşamasında, resimlerde görülen görsel bileşenlerin hangi resimde geçtiği de belirtilerek elektronik tablo sıralanmıştır. Sonraki aşamada sıralanan bu kavramlar gruplanarak temalar oluşturulmuştur. 
Şekil 1. Örnek Ekran Görüntüsü (İspanyolca)

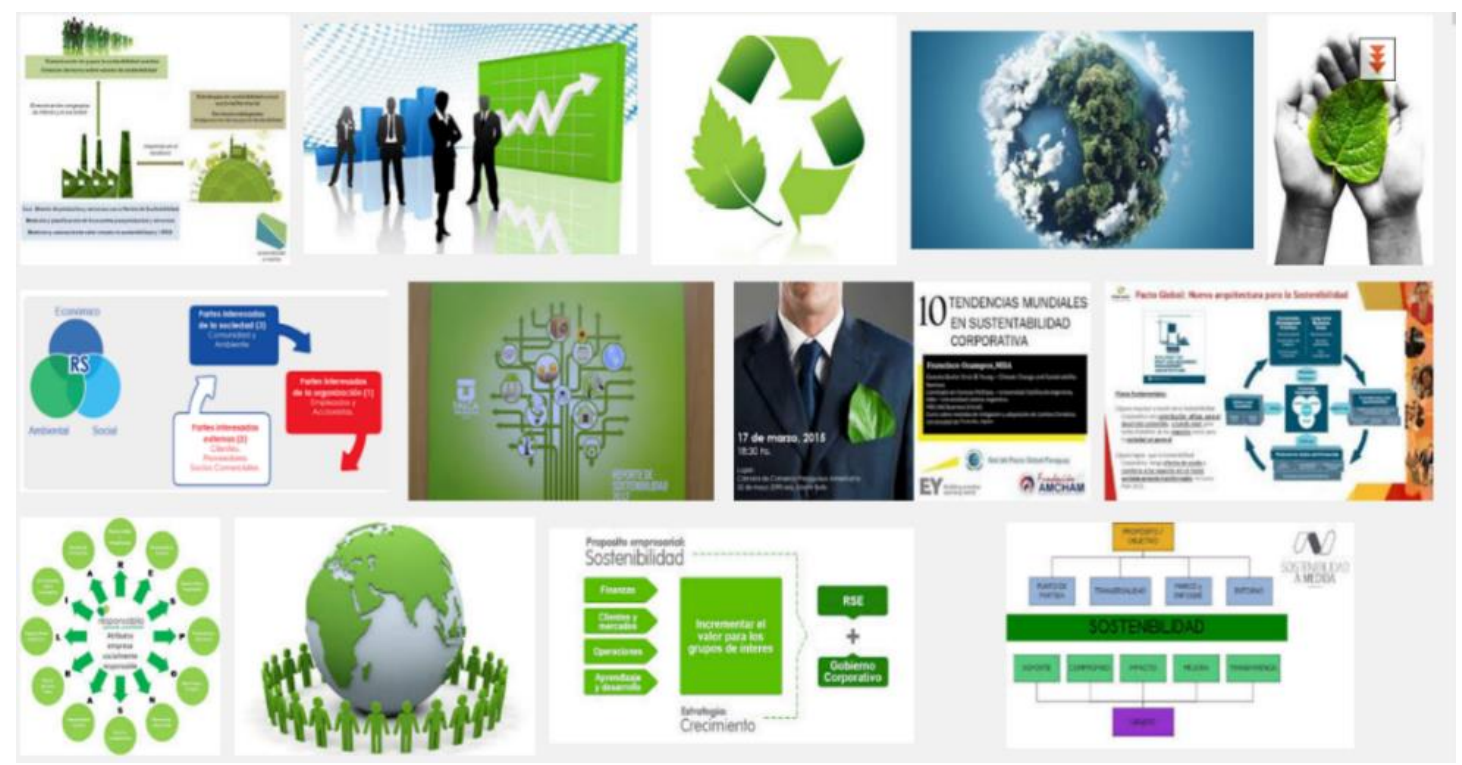

En son aşamada belirlenen kavramlar incelenerek dillere ve temalara göre farklılıklar araştırılmış ve araştırma süreci raporlanmıştır. Resimler üzerinde görülen tüm görsel bileşenler resim numaraları ile birlikte listelendikten sonra (alt tema olarak adlandırdı̆̆ımız) bu listelerde bulunan ögeler temalar altında toplanmıştır. İnceleme sonucu beş ana tema üzerinde karar kılınmıştır. Bu makale boyunca bu temalar "teknoloji”, "sosyal”, “çevre”, "yazı/çizelge/grafik/şema/sembol/şekil (bu noktadan sonra kısaca 'medya' olarak anılmıştır)" ve "diğer” olarak adlandırılmıştır.

Her bir temaya ve dile ait sonuç görsel sayıları ve yüzdeleri, aşağıdaki tablolarda sunulmaktadır. Her tablo, tek bir dilin arama sonuçlarını sunmaktadır. Bu tablolarda sütunlarda sırasıyla (1) tema, (2) görsel isimleri ve (3) seçilen dilde elde edilen resimlerde her bir görselin kaç kez geçtiği gösterilmektedir. Dördüncü sütun ise bir temada yer alan görsellerin bu tema altında yer alan toplam görsel sayısına olan yüzdesini vermektedir. Örneğin Tablo 4'te yer alan sosyal teması altında toplam 10 resim mevcuttur. Bunlardan sekizi insan, biri çocuk, biri ise şehir görselidir. 10 görselden sekizi insan görseli olduğu için sosyal teması altında bulunan görsellerin yüzde sekseni insan görsellerinden meydana gelmiştir. Aynı şekilde sosyal teması altında bulunan çocuk ve şehir görselleri on görselden biri olmaları sebebi ile yüzde on oranındadır denilebilir. Bu tablolardaki beşinci sütun (Toplam) her bir görselin, tema ayrımı gözetmeksizin, bir dile ait tüm görseller içerisindeki oranını vermektedir. Bu şekilde her bir dilde hangi görsellerin en çok yer aldığ 1 daha kolay belirlenebilecektir. Son olarak, son iki sütun genel olarak temaların toplam içindeki sayılarını ve yüzdelerini temsil etmektedir. 


\section{Bulgular ve Yorumlar}

Çalışmanın bulguları, konuşulan diller dikkate alınarak tablolar halinde verilmiştir. Tablo 2, aşağıda ayrıntıları ile verilecek dillere ve temalara ilişkin sinıflandırmaları ve frekansları sunmaktadır.

Tablo 2. Görsellerin dillere ve temalara göre frekansları

\begin{tabular}{|c|c|c|c|c|c|c|c|c|c|c|c|c|c|}
\hline Tema & De & $\mathrm{Ar}$ & $\mathrm{Bn}$ & $\mathrm{Zh}$ & $\mathrm{Fr}$ & En & Es & $\mathrm{Ja}$ & $\mathrm{Pt}$ & $\mathrm{Ru}$ & $\mathrm{Tr}$ & $\mathrm{Ur}$ & Toplam \\
\hline \multirow[t]{2}{*}{ Medya } & 44 & 37 & 29 & 35 & 51 & 31 & 27 & 33 & 35 & 44 & 46 & 28 & 440 \\
\hline & $61,1 \%$ & $52,1 \%$ & $50,0 \%$ & $56,5 \%$ & $72,9 \%$ & $25,8 \%$ & $24,8 \%$ & $53,2 \%$ & $29,2 \%$ & $80,0 \%$ & $38,7 \%$ & $50,9 \%$ & $45,22 \%$ \\
\hline \multirow[t]{2}{*}{ Çevre } & 17 & 12 & 3 & 1 & 12 & 48 & 40 & 2 & 33 & 1 & 35 & 4 & 208 \\
\hline & $23,6 \%$ & $16,9 \%$ & $5,2 \%$ & $1,6 \%$ & $17,1 \%$ & $40,0 \%$ & $36,7 \%$ & $3,2 \%$ & $27,5 \%$ & $1,8 \%$ & $29,4 \%$ & $7,3 \%$ & $21,38 \%$ \\
\hline \multirow[t]{2}{*}{ Diğer } & 8 & 5 & 2 & 9 & 5 & 23 & 13 & 13 & 14 & 2 & 10 & 6 & 110 \\
\hline & $11,1 \%$ & $7,0 \%$ & $3,4 \%$ & $14,5 \%$ & $7,1 \%$ & $19,2 \%$ & $11,9 \%$ & $21,0 \%$ & $11,7 \%$ & $3,6 \%$ & $8,4 \%$ & $10,9 \%$ & 11,31 \\
\hline \multirow[t]{2}{*}{ Sosyal } & 2 & 10 & 19 & 16 & 2 & 10 & 14 & 11 & 11 & 5 & 11 & 17 & 128 \\
\hline & $2,8 \%$ & $14,1 \%$ & $32,8 \%$ & $25,8 \%$ & $2,9 \%$ & $8,3 \%$ & $12,8 \%$ & $17,7 \%$ & $9,2 \%$ & $9,1 \%$ & $9,2 \%$ & $30,9 \%$ & 13,16 \\
\hline \multirow[t]{2}{*}{ Teknoloji } & 1 & 7 & 5 & 1 & 0 & 8 & 15 & 3 & 27 & 3 & 17 & 0 & 87 \\
\hline & $1,4 \%$ & $9,9 \%$ & $8,6 \%$ & $1,6 \%$ & $0,0 \%$ & $6,7 \%$ & $13,8 \%$ & $4,8 \%$ & $22,5 \%$ & $5,5 \%$ & $14,3 \%$ & $0,0 \%$ & 8,94 \\
\hline \multirow[t]{2}{*}{ Toplam } & 72 & 71 & 58 & 62 & 70 & 120 & 109 & 62 & 120 & 55 & 119 & 55 & 973 \\
\hline & $100 \%$ & $100 \%$ & $100 \%$ & $100 \%$ & $100 \%$ & $100 \%$ & $100 \%$ & $100 \%$ & $100 \%$ & $100 \%$ & $100 \%$ & $100 \%$ & $100 \%$ \\
\hline
\end{tabular}

Not. De: Almanca; Ar: Arapça; Bn: Bengalce; Zh: Çince; Fr: Fransızca; En: İngilizce; Es: İspanyolca; Ja: Japonca; Pt: Portekizce; Ru: Rusça; Tr: Türkçe; Ur: Urduca

Genel tablo incelenecek olursa Medya temasının çok baskın olduğu göze çarpar. Genel olarak araştırmaya dâhil edilen dillerde yazı/çizelge/grafik/şema/sembol/şekil vb. sıklıkla kullanılmıştır. Tablo 2'de görüldüğü gibi İspanyolca ve İngilizce ortalamanın altında medya görsellerine sahip iken Rusçada ve Fransızcada medya görselleri genel ortalamanın altındadır.

Çevre ile ilgili görseller medyadan sonra en çok karşılaşılan görsellerdir. Çince ve Rusçada çok az bulunan çevre görselleri İngilizce ve İspanyolca dillerinde ise ortalamanın üstündedir.

Sosyal kategorisi toplam içerisinde yaklaşık \%13'lük bir yer tutar. Fakat bu ortalamayı Çince, Bengalce ve Urduca gibi doğu dillerine ait sonuçlar yukarı çekmektedir.

Teknoloji ile ilgili görseller ise en az karşılaşılan temayı teşkil etmektedirler. Portekizce 'deki yoğun kullanımlarının yanında Almanca, Çince, Fransızca ve Urduca dillerindeki düşük kullanım yüzdeleri dikkat çekicidir. 


\subsection{Almanca}

Genel sonuçlara bakıldığında Almancaya ait tarama sonuçlarının çoğunun şema/grafik/logo/yazı vb. ögelerden oluştuğu görülmektedir (Tablo 3). Çevreyi temsil eden görsel ögeler ise ikinci sırada gelmektedir. Bu iki temanın dışında yer alan tüm gruplar ise toplamın ancak küçük bir yüzdesini oluşturmaktadır. Özellikle sosyal ve teknoloji temalarına ait görsellerin azlığı dikkat çekicidir.

Çevre temasının ayrıntılarına bakıldığında çevreyi temsil etmek için en çok dünya ve yaprak görsellerinin kullanıldığı görülmektedir. Almancada teknolojiye yönelik görseller incelendiğinde ise yalnızca bir adet araba resmine rastlanmaktadır. Sosyal temasına ait iki görselin ikisi de insan figürüdür. Bunun dışında el görseli de Almancada görece çok rastlanan figürler arasındadır. Bunun dışında grafik yazı ve şemalara sıklıkla rastlanmaktadir.

Tablo 3. Almanca tema sonuçları

\begin{tabular}{|c|c|c|c|c|c|c|}
\hline \multirow[b]{3}{*}{ Tema } & \multirow[b]{3}{*}{ Alt Tema } & \multicolumn{3}{|c|}{ Alt Tema } & \multirow{2}{*}{\multicolumn{2}{|c|}{ Tema }} \\
\hline & & \multicolumn{2}{|r|}{ Tema İçinde } & \multirow{2}{*}{$\frac{\text { Toplamda }}{\%}$} & & \\
\hline & & $n$ & $\%$ & & $n$ & $\%$ \\
\hline \multirow[t]{7}{*}{ Çevre } & Dünya & 6 & $35,3 \%$ & $8,3 \%$ & 17 & $24,0 \%$ \\
\hline & Yaprak & 4 & $23,5 \%$ & $5,6 \%$ & & \\
\hline & Ağaç & 2 & $11,8 \%$ & $2,8 \%$ & & \\
\hline & Geri dönüşüm & 2 & $11,8 \%$ & $2,8 \%$ & & \\
\hline & Damla & 1 & $5,9 \%$ & $1,4 \%$ & & \\
\hline & Toprak & 1 & $5,9 \%$ & $1,4 \%$ & & \\
\hline & Çimen & 1 & $5,9 \%$ & $1,4 \%$ & & \\
\hline Teknoloji & Araba & 1 & $100,0 \%$ & $1,4 \%$ & 1 & $1,0 \%$ \\
\hline Sosyal & İnsan & 2 & $100,0 \%$ & $2,8 \%$ & 2 & $3,0 \%$ \\
\hline \multirow[t]{2}{*}{ Diğer } & $\mathrm{El}$ & 7 & $87,5 \%$ & $9,7 \%$ & 8 & $11,0 \%$ \\
\hline & Yumurta & 1 & $12,5 \%$ & $1,4 \%$ & & \\
\hline \multirow[t]{6}{*}{ Medya } & Grafik & 12 & $27,3 \%$ & $16,7 \%$ & 44 & $61,0 \%$ \\
\hline & Metin & 10 & $22,7 \%$ & $13,9 \%$ & & \\
\hline & Şema & 10 & $22,7 \%$ & $13,9 \%$ & & \\
\hline & Logo & 8 & $18,2 \%$ & $11,1 \%$ & & \\
\hline & Çizim & 3 & $6,8 \%$ & $4,2 \%$ & & \\
\hline & Resim & 1 & $2,3 \%$ & $1,4 \%$ & & \\
\hline Toplam & & 72 & & $100,0 \%$ & 72 & $100,0 \%$ \\
\hline
\end{tabular}

\subsection{Arapça}

Arapçada "Kurumsal Sürdürülebilirlik" “"الاستدامةللثركات" şeklinde ifade edilmektedir. $\mathrm{Bu}$ dilde yapilan taramayla elde edilen 50 resmin incelenmesi ile 
oluşturulan temalar ve her bir temanın içerdiği görsellerin frekans ve yüzdeleri Tablo 4'te görülmektedir. Elde edilen resimlerde bulunan görsel ögelerin yarıdan fazlası yazı, şema vb. oluşmaktadır. Geri kalanlar ise sırası ile çevre, sosyal, teknoloji ve diğer temalarından oluşmaktadır.

Tablo 4. Arapça tema sonuçları

\begin{tabular}{|c|c|c|c|c|c|c|}
\hline \multirow[b]{3}{*}{ Tema } & \multirow[b]{3}{*}{ Alt Tema } & \multicolumn{3}{|c|}{ Alt Tema } & \multirow{2}{*}{\multicolumn{2}{|c|}{ Tema }} \\
\hline & & \multicolumn{2}{|c|}{ Tema İçind } & Toplamda & & \\
\hline & & $N$ & $\%$ & $\%$ & $n$ & $\%$ \\
\hline \multirow[t]{7}{*}{ Çevre } & Dünya & 3 & $25,0 \%$ & $4,2 \%$ & 12 & $16,9 \%$ \\
\hline & Ăgaç & 2 & $16,7 \%$ & $2,8 \%$ & & \\
\hline & Yaprak & 2 & $16,7 \%$ & $2,8 \%$ & & \\
\hline & Çiçek & 2 & $16,7 \%$ & $2,8 \%$ & & \\
\hline & Geri dönüşüm & 1 & $8,3 \%$ & $1,4 \%$ & & \\
\hline & $\mathrm{CO}_{2}$ & 1 & $8,3 \%$ & $1,4 \%$ & & \\
\hline & Güneş & 1 & $8,3 \%$ & $1,4 \%$ & & \\
\hline \multirow[t]{4}{*}{ Teknoloji } & Fabrika & 3 & $42,9 \%$ & $4,2 \%$ & 7 & $9,9 \%$ \\
\hline & Güneş paneli & 2 & $28,6 \%$ & $2,8 \%$ & & \\
\hline & Bilgisayar & 1 & $14,3 \%$ & $1,4 \%$ & & \\
\hline & Tren & 1 & $14,3 \%$ & $1,4 \%$ & & \\
\hline \multirow[t]{3}{*}{ Sosyal } & İnsan & 8 & $80,0 \%$ & $11,3 \%$ & 10 & $14,1 \%$ \\
\hline & Şehir & 1 & $10,0 \%$ & $1,4 \%$ & & \\
\hline & Çocuk & 1 & $10,0 \%$ & $1,4 \%$ & & \\
\hline \multirow[t]{4}{*}{ Diğger } & $\mathrm{El}$ & 2 & $40,0 \%$ & $2,8 \%$ & 5 & $7,0 \%$ \\
\hline & Çizgi film & 1 & $20,0 \%$ & $1,4 \%$ & & \\
\hline & Para & 1 & $20,0 \%$ & $1,4 \%$ & & \\
\hline & Dolma kalem & 1 & $20,0 \%$ & $1,4 \%$ & & \\
\hline \multirow[t]{6}{*}{ Medya } & Logo & 23 & $62,2 \%$ & $32,4 \%$ & 37 & $52,1 \%$ \\
\hline & Grafik & 6 & $16,2 \%$ & $8,5 \%$ & & \\
\hline & Metin & 4 & $10,8 \%$ & $5,6 \%$ & & \\
\hline & Çizim & 2 & $5,4 \%$ & $2,8 \%$ & & \\
\hline & Şema & 1 & $2,7 \%$ & $1,4 \%$ & & \\
\hline & Resim & 1 & $2,7 \%$ & $1,4 \%$ & & \\
\hline Toplam & & 71 & & $100,0 \%$ & 71 & $100,0 \%$ \\
\hline
\end{tabular}

Çevre teması içerisinde en çok dünya görseline rastlanmaktadır. Bunu ağaç, yaprak ve çiçek gibi figürler takip etmektedir. Teknoloji teması altında ise fabrika ve güneş paneli gibi görseller yer almaktadır. Tüm görseller içinde en çok logo görselleri yer almaktadir. 


\subsection{Bengalce}

Bengalce içerisinde yer alan görsellerin yarısı medya teması içinde yer almaktadır (Tablo 5). Bunu yüzde otuz üç ile sosyal teması izlemektedir. Diğer temalar görece düşük sayıda görsel içermektedir.

Tablo 5. Bengalce tema sonuçları

\begin{tabular}{|c|c|c|c|c|c|c|}
\hline \multirow[b]{3}{*}{ Tema } & \multirow[b]{3}{*}{ Alt Tema } & \multicolumn{3}{|c|}{ Alt Tema } & \multirow{2}{*}{\multicolumn{2}{|c|}{ Tema }} \\
\hline & & \multicolumn{2}{|r|}{ Tema İçinde } & \multirow{2}{*}{$\frac{\text { Toplamda }}{\%}$} & & \\
\hline & & $n$ & $\%$ & & $n$ & $\%$ \\
\hline \multirow[t]{2}{*}{ Çevre } & Dünya & 2 & $66,7 \%$ & $3,4 \%$ & 3 & $5,2 \%$ \\
\hline & Çimen & 1 & $33,3 \%$ & $1,7 \%$ & & \\
\hline \multirow[t]{3}{*}{ Teknoloji } & Telefon logosu & 3 & $60,0 \%$ & $5,2 \%$ & 5 & $8,6 \%$ \\
\hline & Araba & 1 & $20,0 \%$ & $1,7 \%$ & & \\
\hline & Güneş paneli & 1 & $20,0 \%$ & $1,7 \%$ & & \\
\hline Sosyal & İnsan & 19 & $100,0 \%$ & $32,8 \%$ & 19 & $32,8 \%$ \\
\hline \multirow[t]{2}{*}{ Diğer } & Satranç & 1 & $50,0 \%$ & $1,7 \%$ & 2 & $3,4 \%$ \\
\hline & $\mathrm{El}$ & 1 & $50,0 \%$ & $1,7 \%$ & & \\
\hline \multirow[t]{4}{*}{ Medya } & Metin & 17 & $58,6 \%$ & $29,3 \%$ & 29 & $50,0 \%$ \\
\hline & Logo & 7 & $24,1 \%$ & $12,1 \%$ & & \\
\hline & Resim & 4 & $13,8 \%$ & $6,9 \%$ & & \\
\hline & Grafik & 1 & $3,4 \%$ & $1,7 \%$ & & \\
\hline Toplam & & 58 & & $100,0 \%$ & 58 & $100,0 \%$ \\
\hline
\end{tabular}

Bengalcede diğer dillere oranla insan figürü daha çok görülmektedir. Diğer bazı dillerde (Örneğin Arapça, Fransızca, Çince vb.) olduğu gibi yazı/şekil de çok görülen görseller arasındadır.

\section{4. Çince}

Çincede yer alan görsellerin yarıdan fazlası medya temasına aittir (Tablo 6). Bunu takiben en çok görsel \%26 oranla sosyal kategorisinde yer almaktadır. Çevre ve teknoloji temalarında ise yalnızca birer görsel mevcuttur. 
Tablo 6. Çince tema sonuçları

\begin{tabular}{|c|c|c|c|c|c|c|}
\hline \multirow[b]{3}{*}{ Tema } & \multirow[b]{3}{*}{ Alt Tema } & \multicolumn{3}{|c|}{ Alt Tema } & \multirow{2}{*}{\multicolumn{2}{|c|}{ Tema }} \\
\hline & & \multicolumn{3}{|c|}{ Tema İçinde Toplamda } & & \\
\hline & & $n$ & $\%$ & $\%$ & $n$ & $\%$ \\
\hline Çevre & Yaprak & 1 & $100,0 \%$ & $1,6 \%$ & 1 & $1,6 \%$ \\
\hline Teknoloji & Bina & 1 & $100,0 \%$ & $1,6 \%$ & 1 & $1,6 \%$ \\
\hline \multirow[t]{2}{*}{ Sosyal } & İnsan & 11 & $68,8 \%$ & $17,7 \%$ & 16 & $25,8 \%$ \\
\hline & Ödül kazanan insanlar & 5 & $31,3 \%$ & $8,1 \%$ & & \\
\hline \multirow[t]{6}{*}{ Diğer } & Kitap & 4 & $44,4 \%$ & $6,5 \%$ & 9 & $14,5 \%$ \\
\hline & Koltuk & 1 & $11,1 \%$ & $1,6 \%$ & & \\
\hline & Defter & 1 & $11,1 \%$ & $1,6 \%$ & & \\
\hline & Dolma kalem & 1 & $11,1 \%$ & $1,6 \%$ & & \\
\hline & Ödül & 1 & $11,1 \%$ & $1,6 \%$ & & \\
\hline & $\mathrm{El}$ & 1 & $11,1 \%$ & $1,6 \%$ & & \\
\hline \multirow[t]{6}{*}{ Medya } & Metin & 17 & $48,6 \%$ & $27,4 \%$ & 35 & $56,5 \%$ \\
\hline & Çizim & 8 & $22,9 \%$ & $12,9 \%$ & & \\
\hline & Grafik & 6 & $17,1 \%$ & $9,7 \%$ & & \\
\hline & Resim & 2 & $5,7 \%$ & $3,2 \%$ & & \\
\hline & Logo & 1 & $2,9 \%$ & $1,6 \%$ & & \\
\hline & Dolar & 1 & $2,9 \%$ & $1,6 \%$ & & \\
\hline Toplam & & 62 & & $100,0 \%$ & 62 & $100,0 \%$ \\
\hline
\end{tabular}

Çince temasında çevre ve teknolojiye ait görseller oldukça azdır. En çok görsel içeren medya temasında yer alan 35 görseli, sosyal temasında yer alan 16 görsel izlemektedir. Bunun dişında Çincede yer alan 4 adet kitap görseli de ilgi çekicidir.

\subsection{Fransizca}

Fransızcadaki toplam 70 görselin 51'i (\%73) medya temasına aittir (Tablo 7). Teknoloji temasında hiç görsel yer almaması ilgi çekicidir. Bunun dışında çevre temasındaki görseller dışında diğer temalarda da (teknoloji, sosyal, vb.) oldukça az sayıda görsel bulunmaktadır. 
Mustafa Nuri URAL, Özlem TUNA, “Kurumsal Sürdürülebilirliğin Dünyanın En Çok Konuşulan Dillerinde Çevrimiçi Görsel Algısı”, Mavi Atlas, 7(2)/2019: 220-242

Tablo 7. Fransızca tema sonuçları

\begin{tabular}{|c|c|c|c|c|c|c|}
\hline \multirow[b]{3}{*}{ Tema } & \multirow[b]{3}{*}{ Alt Tema } & \multicolumn{3}{|c|}{ Alt Tema } & \multirow{2}{*}{\multicolumn{2}{|c|}{ Tema }} \\
\hline & & \multicolumn{2}{|r|}{ Tema İçinde } & \multirow{2}{*}{$\frac{\text { Toplamda }}{\%}$} & & \\
\hline & & $n$ & $\%$ & & $n$ & $\%$ \\
\hline \multirow[t]{8}{*}{ Çevre } & Ăgaç & 2 & $16,7 \%$ & $2,9 \%$ & 12 & $17,1 \%$ \\
\hline & Gökyüzü & 2 & $16,7 \%$ & $2,9 \%$ & & \\
\hline & Çimen & 2 & $16,7 \%$ & $2,9 \%$ & & \\
\hline & Bulut & 2 & $16,7 \%$ & $2,9 \%$ & & \\
\hline & Dünya & 1 & $8,3 \%$ & $1,4 \%$ & & \\
\hline & Geri dönüşüm & 1 & $8,3 \%$ & $1,4 \%$ & & \\
\hline & Toprak & 1 & $8,3 \%$ & $1,4 \%$ & & \\
\hline & İnek & 1 & $8,3 \%$ & $1,4 \%$ & & \\
\hline Teknoloji & Teknoloji & 0 & $0,0 \%$ & $0,0 \%$ & 0 & $0,0 \%$ \\
\hline Sosyal & İnsan & 2 & $100,0 \%$ & $2,9 \%$ & 2 & $2,9 \%$ \\
\hline \multirow[t]{4}{*}{ Diğer } & $\mathrm{El}$ & 2 & $40,0 \%$ & $2,9 \%$ & 5 & $7,1 \%$ \\
\hline & Kitap & 1 & $20,0 \%$ & $1,4 \%$ & & \\
\hline & Sandviç & 1 & $20,0 \%$ & $1,4 \%$ & & \\
\hline & Para & 1 & $20,0 \%$ & $1,4 \%$ & & \\
\hline \multirow[t]{6}{*}{ Medya } & Şema & 22 & $43,1 \%$ & $31,4 \%$ & 51 & $72,9 \%$ \\
\hline & Grafik & 12 & $23,5 \%$ & $17,1 \%$ & & \\
\hline & Metin & 7 & $13,7 \%$ & $10,0 \%$ & & \\
\hline & Çizim & 6 & $11,8 \%$ & $8,6 \%$ & & \\
\hline & Resim & 3 & $5,9 \%$ & $4,3 \%$ & & \\
\hline & Logo & 1 & $2,0 \%$ & $1,4 \%$ & & \\
\hline Toplam & & 70 & & $100,0 \%$ & 70 & $100,0 \%$ \\
\hline
\end{tabular}

Fransızcada en çok şema ve grafiklere rastlanmaktadır. Bunun dışında yer alan görseller oldukça düşük frekansa sahiptir. Bu frekansların dağılımı Tablo 7'den de görülebilir.

\section{6. İngilizce}

İngilizcede yer alan görseller içerisinde en çok çevre teması ile ilgili olanlar göze çarpmaktadır (Tablo 8). Diğer dillerle benzer biçimde medya teması altında da oldukça fazla görsel mevcuttur. 
Tablo 8. İngilizce tema sonuçları

\begin{tabular}{|c|c|c|c|c|c|c|}
\hline \multirow[b]{3}{*}{ Tema } & \multirow[b]{3}{*}{ Alt Tema } & \multicolumn{3}{|c|}{ Alt Tema } & \multirow{2}{*}{\multicolumn{2}{|c|}{ Tema }} \\
\hline & & \multicolumn{2}{|c|}{ Tema İçinc } & Toplamda & & \\
\hline & & $n$ & $\%$ & $\%$ & $n$ & $\%$ \\
\hline \multirow{7}{*}{ Çevre } & Dünya & 17 & $35,4 \%$ & $14,2 \%$ & 48 & $40,0 \%$ \\
\hline & Çimen & 11 & $22,9 \%$ & $9,2 \%$ & & \\
\hline & Ăğaç & 8 & $16,7 \%$ & $6,7 \%$ & & \\
\hline & Yaprak & 6 & $12,5 \%$ & $5,0 \%$ & & \\
\hline & Geri dönüşüm & 4 & $8,3 \%$ & $3,3 \%$ & & \\
\hline & Çöp & 1 & $2,1 \%$ & $0,8 \%$ & & \\
\hline & Kuş & 1 & $2,1 \%$ & $0,8 \%$ & & \\
\hline \multirow[t]{3}{*}{ Teknoloji } & Rüzgâr türbini & 4 & $50,0 \%$ & $3,3 \%$ & 8 & $6,7 \%$ \\
\hline & Araba & 2 & $25,0 \%$ & $1,7 \%$ & & \\
\hline & Bina & 2 & $25,0 \%$ & $1,7 \%$ & & \\
\hline \multirow[t]{3}{*}{ Sosyal } & İnsan & 8 & $80,0 \%$ & $6,7 \%$ & 10 & $8,3 \%$ \\
\hline & Kızıl haç & 1 & $10,0 \%$ & $0,8 \%$ & & \\
\hline & Kalp & 1 & $10,0 \%$ & $0,8 \%$ & & \\
\hline \multirow[t]{5}{*}{ Diğer } & $\mathrm{El}$ & 13 & $56,5 \%$ & $10,8 \%$ & 23 & $19,2 \%$ \\
\hline & Ampul & 4 & $17,4 \%$ & $3,3 \%$ & & \\
\hline & Dolar işareti & 4 & $17,4 \%$ & $3,3 \%$ & & \\
\hline & Koltuk & 1 & $4,3 \%$ & $0,8 \%$ & & \\
\hline & Yol & 1 & $4,3 \%$ & $0,8 \%$ & & \\
\hline \multirow[t]{4}{*}{ Medya } & Çizim & 9 & $29,0 \%$ & $7,5 \%$ & 31 & $25,8 \%$ \\
\hline & Metin & 9 & $29,0 \%$ & $7,5 \%$ & & \\
\hline & Grafik & 7 & $22,6 \%$ & $5,8 \%$ & & \\
\hline & Şema & 6 & $19,4 \%$ & $5,0 \%$ & & \\
\hline Toplam & & 120 & & $100,0 \%$ & 120 & $100,0 \%$ \\
\hline
\end{tabular}

Görsellerin temalara göre dağılımı Tablo 8'de görülebilir. Diğer bazı dillerde (Almanca, İspanyolca, Portekizce, vb.) de olduğu gibi çevre teması içerisinde dünya, çimen, ağaç ve yaprak sıklıkla görülen görsellerdir. Bunun dışında el görseli yine çok rastlanan görseller arasındadır. İngilizceye ait görsellerden 31 tanesi ise medya temasına aittir.

\section{7. İspanyolca}

İspanyolcaya ait görseller incelendiğinde en çok çevre temasına ait görsellerin yer aldığı görülmektedir (Tablo 9). Bunu medya teması izlemektedir. İspanyolca, çevre teması ile ilgili görsellerin frekansının medyadan fazla olduğu nadir diller arasındadır. 
Tablo 9. İspanyolca tema sonuçları

\begin{tabular}{|c|c|c|c|c|c|c|}
\hline \multirow[b]{3}{*}{ Tema } & \multirow[b]{3}{*}{ Alt Tema } & \multicolumn{3}{|c|}{ Alt Tema } & \multirow{2}{*}{\multicolumn{2}{|c|}{ Tema }} \\
\hline & & \multicolumn{2}{|c|}{ Tema İçind } & $\overline{\text { Toplamda }}$ & & \\
\hline & & $n$ & $\%$ & $\%$ & $n$ & $\%$ \\
\hline \multirow[t]{9}{*}{ Çevre } & Dünya & 17 & $42,5 \%$ & $15,6 \%$ & 40 & $36,7 \%$ \\
\hline & Ağaç & 5 & $12,5 \%$ & $4,6 \%$ & & \\
\hline & Yaprak & 5 & $12,5 \%$ & $4,6 \%$ & & \\
\hline & Çimen & 5 & $12,5 \%$ & $4,6 \%$ & & \\
\hline & Geri dönüşüm & 4 & $10,0 \%$ & $3,7 \%$ & & \\
\hline & Toprak & 1 & $2,5 \%$ & $0,9 \%$ & & \\
\hline & Kuş & 1 & $2,5 \%$ & $0,9 \%$ & & \\
\hline & Çiçek & 1 & $2,5 \%$ & $0,9 \%$ & & \\
\hline & Karbon ayak izi & 1 & $2,5 \%$ & $0,9 \%$ & & \\
\hline \multirow[t]{12}{*}{ Teknoloji } & Binalar & 3 & $20,0 \%$ & $2,8 \%$ & 15 & $13,8 \%$ \\
\hline & Rüzgâr türbini & 2 & $13,3 \%$ & $1,8 \%$ & & \\
\hline & Ampul & 1 & $6,7 \%$ & $0,9 \%$ & & \\
\hline & Elektrik hattı & 1 & $6,7 \%$ & $0,9 \%$ & & \\
\hline & Uçak & 1 & $6,7 \%$ & $0,9 \%$ & & \\
\hline & Araba & 1 & $6,7 \%$ & $0,9 \%$ & & \\
\hline & Gemi & 1 & $6,7 \%$ & $0,9 \%$ & & \\
\hline & Bisiklet & 1 & $6,7 \%$ & $0,9 \%$ & & \\
\hline & Pusula & 1 & $6,7 \%$ & $0,9 \%$ & & \\
\hline & Fabrika & 1 & $6,7 \%$ & $0,9 \%$ & & \\
\hline & Tekerlek & 1 & $6,7 \%$ & $0,9 \%$ & & \\
\hline & Megafon & 1 & $6,7 \%$ & $0,9 \%$ & & \\
\hline \multirow[t]{2}{*}{ Sosyal } & İnsan & 13 & $92,9 \%$ & $11,9 \%$ & 14 & $12,8 \%$ \\
\hline & $\mathrm{Ev}$ & 1 & $7,1 \%$ & $0,9 \%$ & & \\
\hline \multirow[t]{4}{*}{ Diğer } & $\mathrm{El}$ & 10 & $76,9 \%$ & $9,2 \%$ & 13 & $11,9 \%$ \\
\hline & Ticaret & 1 & $7,7 \%$ & $0,9 \%$ & & \\
\hline & Para sembolü & 1 & $7,7 \%$ & $0,9 \%$ & & \\
\hline & Dağlar & 1 & $7,7 \%$ & $0,9 \%$ & & \\
\hline \multirow{6}{*}{ Medya } & Grafik & 8 & $29,6 \%$ & $7,3 \%$ & 27 & $24,8 \%$ \\
\hline & Şema & 7 & $25,9 \%$ & $6,4 \%$ & & \\
\hline & Metin & 5 & $18,5 \%$ & $4,6 \%$ & & \\
\hline & Logo & 4 & $14,8 \%$ & $3,7 \%$ & & \\
\hline & Çizim & 2 & $7,4 \%$ & $1,8 \%$ & & \\
\hline & Resim & 1 & $3,7 \%$ & $0,9 \%$ & & \\
\hline Toplam & & 109 & & $100,0 \%$ & 109 & $100,0 \%$ \\
\hline
\end{tabular}

İspanyolcanın çevre teması altında en çok dünya görseline rastlanmaktadır. Çevre temasında ayrıca, ağaç, yaprak ve çimen gibi görseller çoğunluktadır. El görseli İspanyolcada da çok rastlanan görseller arasındadır. Medya temasına ait 27 görsele rastlanmıştır. 


\subsection{Japonca}

Japoncaya ait görsellerin yarıdan fazlası medya temasına aittir (Tablo 10). Özellikle çevre ve teknoloji temasına ait görseller bu dilde de oldukça düşük bir frekansa sahiptir.

Tablo 10. Japonca tema sonuçları

\begin{tabular}{|c|c|c|c|c|c|c|}
\hline \multirow[b]{3}{*}{ Tema } & \multirow[b]{3}{*}{ Alt Tema } & \multicolumn{3}{|c|}{ Alt Tema } & \multirow{2}{*}{\multicolumn{2}{|c|}{ Tema }} \\
\hline & & \multicolumn{2}{|r|}{ Tema İçind } & \multirow{2}{*}{$\frac{\text { Toplamda }}{\%}$} & & \\
\hline & & $n$ & $\%$ & & $n$ & $\%$ \\
\hline \multirow[t]{2}{*}{ Çevre } & Dünya & 1 & $50,0 \%$ & $1,6 \%$ & 2 & $3,2 \%$ \\
\hline & Üzümler & 1 & $50,0 \%$ & $1,6 \%$ & & \\
\hline \multirow[t]{2}{*}{ Teknoloji } & Bina & 2 & $66,7 \%$ & $3,2 \%$ & 3 & $4,8 \%$ \\
\hline & Araba & 1 & $33,3 \%$ & $1,6 \%$ & & \\
\hline Sosyal & İnsan & 11 & $100,0 \%$ & $17,7 \%$ & 11 & $17,7 \%$ \\
\hline \multirow[t]{2}{*}{ Diğer } & Kitap kapağ1 & 11 & $84,6 \%$ & $17,7 \%$ & 13 & $21,0 \%$ \\
\hline & Kitap & 2 & $15,4 \%$ & $3,2 \%$ & & \\
\hline \multirow[t]{7}{*}{ Medya } & Metin & 14 & $42,4 \%$ & $22,6 \%$ & 33 & $53,2 \%$ \\
\hline & Şema & 7 & $21,2 \%$ & $11,3 \%$ & & \\
\hline & Logo & 5 & $15,2 \%$ & $8,1 \%$ & & \\
\hline & Çizim & 3 & $9,1 \%$ & $4,8 \%$ & & \\
\hline & Resim & 2 & $6,1 \%$ & $3,2 \%$ & & \\
\hline & Sembol & 1 & $3,0 \%$ & $1,6 \%$ & & \\
\hline & Şekil & 1 & $3,0 \%$ & $1,6 \%$ & & \\
\hline Toplam & & 62 & & $100,0 \%$ & 62 & $100,0 \%$ \\
\hline
\end{tabular}

14 adet yazının ardından Japoncada en çok insan ve kitap (Çince ile benzer biçimde) ile ilgili görseller mevcuttur.

\subsection{Portekizce}

Portekizce görseller incelendiğinde yazı teması çevre teması ve teknoloji teması birbirlerine yakın oranlarda yer almaktadır (Tablo 11). Portekizcede toplam 120 görsel incelenmiştir. Bu temalardan en az görsele sahip olan ise sosyal temasıdır. 
Tablo 11. Portekizce tema sonuçları

\begin{tabular}{|c|c|c|c|c|c|c|}
\hline \multirow[b]{3}{*}{ Tema } & \multirow[b]{3}{*}{ Alt Tema } & \multicolumn{3}{|c|}{ Alt Tema } & \multirow{2}{*}{\multicolumn{2}{|c|}{ Tema }} \\
\hline & & \multicolumn{2}{|c|}{ Tema İçind } & Toplamda & & \\
\hline & & $n$ & $\%$ & $\%$ & $n$ & $\%$ \\
\hline \multirow[t]{8}{*}{ Çevre } & Dünya & 11 & $33,3 \%$ & $9,2 \%$ & 33 & $27,5 \%$ \\
\hline & Ağaç & 7 & $21,2 \%$ & $5,8 \%$ & & \\
\hline & Çimen & 4 & $12,1 \%$ & $3,3 \%$ & & \\
\hline & Geri dönüşüm & 4 & $12,1 \%$ & $3,3 \%$ & & \\
\hline & Yaprak & 3 & $9,1 \%$ & $2,5 \%$ & & \\
\hline & Panda & 2 & $6,1 \%$ & $1,7 \%$ & & \\
\hline & Çöp & 1 & $3,0 \%$ & $0,8 \%$ & & \\
\hline & $\mathrm{CO}_{2}$ & 1 & $3,0 \%$ & $0,8 \%$ & & \\
\hline \multirow[t]{13}{*}{ Teknoloji } & Ampul & 7 & $25,9 \%$ & $5,8 \%$ & 27 & $22,5 \%$ \\
\hline & Bisiklet & 3 & $11,1 \%$ & $2,5 \%$ & & \\
\hline & Fabrika & 3 & $11,1 \%$ & $2,5 \%$ & & \\
\hline & Araba & 2 & $7,4 \%$ & $1,7 \%$ & & \\
\hline & Kalp & 2 & $7,4 \%$ & $1,7 \%$ & & \\
\hline & Gen & 2 & $7,4 \%$ & $1,7 \%$ & & \\
\hline & Aş1 & 2 & $7,4 \%$ & $1,7 \%$ & & \\
\hline & Musluk & 1 & $3,7 \%$ & $0,8 \%$ & & \\
\hline & Priz & 1 & $3,7 \%$ & $0,8 \%$ & & \\
\hline & Bina & 1 & $3,7 \%$ & $0,8 \%$ & & \\
\hline & Bilgisayar & 1 & $3,7 \%$ & $0,8 \%$ & & \\
\hline & Mikroskop & 1 & $3,7 \%$ & $0,8 \%$ & & \\
\hline & Rüzgâr türbini & 1 & $3,7 \%$ & $0,8 \%$ & & \\
\hline Sosyal & İnsan & 11 & $100,0 \%$ & $9,2 \%$ & 11 & $9,2 \%$ \\
\hline \multirow[t]{3}{*}{ Diğer } & $\mathrm{El}$ & 6 & $42,9 \%$ & $5,0 \%$ & 14 & $11,7 \%$ \\
\hline & Kitap kapağı & 5 & $35,7 \%$ & $4,2 \%$ & & \\
\hline & Para sembolü & 3 & $21,4 \%$ & $2,5 \%$ & & \\
\hline \multirow[t]{6}{*}{ Medya } & Metin & 13 & $37,1 \%$ & $10,8 \%$ & 35 & $29,2 \%$ \\
\hline & Şema & 12 & $34,3 \%$ & $10,0 \%$ & & \\
\hline & Çizim & 4 & $11,4 \%$ & $3,3 \%$ & & \\
\hline & Grafik & 4 & $11,4 \%$ & $3,3 \%$ & & \\
\hline & Logo & 2 & $5,7 \%$ & $1,7 \%$ & & \\
\hline & & & & & 12 & \\
\hline Toplam & & 120 & & $100,0 \%$ & 0 & $100,0 \%$ \\
\hline
\end{tabular}

Dünya ve ağaç görselleri Portekizcede de önemli ölçüde yer almaktadır. Bunun dışında teknoloji teması altında en çok rastlanan görsel ampul olmuştur. Medya teması altında yer alan 35 görselin yanı sıra insan görseline de Portekizcede sıklıkla rastlanmıştır.

\subsection{Rusça}

Rusçada yazı dışında kalan temalar oldukça az sayıda görsel içermektedir. Analiz edilen resimlerin büyük çoğunluğu yalnızca logo, çizim ve grafiklerden oluşmaktadır. Bu dağılımların ayrıntısı Tablo 12'de verilmiştir. 
Tablo 12. Rusça tema sonuçları

\begin{tabular}{|c|c|c|c|c|c|c|}
\hline \multirow[b]{3}{*}{ Tema } & \multirow[b]{3}{*}{ Alt Tema } & \multicolumn{3}{|c|}{ Alt Tema } & \multirow{2}{*}{\multicolumn{2}{|c|}{ Tema }} \\
\hline & & \multicolumn{2}{|c|}{ Tema İçinc } & Toplamda & & \\
\hline & & $n$ & $\%$ & $\%$ & $n$ & $\%$ \\
\hline Çevre & Dünya & 1 & $100,0 \%$ & $1,8 \%$ & 1 & $1,8 \%$ \\
\hline \multirow[t]{2}{*}{ Teknoloji } & Araba & 2 & $67,0 \%$ & $3,6 \%$ & 3 & $5,5 \%$ \\
\hline & Bina & 1 & $33,0 \%$ & $1,8 \%$ & & \\
\hline Sosyal & İnsan & 5 & $100,0 \%$ & $9,1 \%$ & 5 & $9,1 \%$ \\
\hline Diğer & Kitap kapağı & 2 & $100,0 \%$ & $3,6 \%$ & 2 & $3,6 \%$ \\
\hline \multirow[t]{6}{*}{ Medya } & Metin & 32 & $73,0 \%$ & $58,2 \%$ & 44 & $80,0 \%$ \\
\hline & Logo & 5 & $11,0 \%$ & $9,1 \%$ & & \\
\hline & Çizim & 3 & $7,0 \%$ & $5,5 \%$ & & \\
\hline & Grafik & 2 & $5,0 \%$ & $3,6 \%$ & & \\
\hline & Şema & 1 & $2,0 \%$ & $1,8 \%$ & & \\
\hline & Resim & 1 & $2,0 \%$ & $1,8 \%$ & & \\
\hline Toplam & & 55 & & $100,0 \%$ & 55 & $100,0 \%$ \\
\hline
\end{tabular}

Rusçada 44 adet medya temasına ait görsel tespit edilmiş bunu beş adet insan görseli izlemektedir. Diğer görseller çok düşük frekanslara sahiptir.

\subsection{Türkçe}

Türkçe görseller de en çok medya temasını takiben çevre ile ilgili görseller yer almaktadır. Türkçede yer alan tüm temalara ait ayrıntılar Tablo 13'ten incelenebilir.

Çevre teması altında en çok ağaç ve dünya görselleri yer almaktadır. Bunun dışında insan, kitap ve el görsellerine de Türkçede birçok kez rastlanmıştır. Medya temasında ise 46 görsel mevcuttur. 
Tablo 13. Türkçe tema sonuçları

\begin{tabular}{|c|c|c|c|c|c|c|}
\hline \multirow[b]{3}{*}{ Tema } & \multirow[b]{3}{*}{ Alt Tema } & \multicolumn{3}{|c|}{ Alt Tema } & \multirow{2}{*}{\multicolumn{2}{|c|}{ Tema }} \\
\hline & & \multicolumn{3}{|c|}{ Tema İçinde Toplamda } & & \\
\hline & & $n$ & $\%$ & $\%$ & $n$ & $\%$ \\
\hline \multirow[t]{6}{*}{ Çevre } & Ağaç & 12 & $34,3 \%$ & $10,1 \%$ & 35 & $29,4 \%$ \\
\hline & Dünya & 10 & $28,6 \%$ & $8,4 \%$ & & \\
\hline & Çimen & 5 & $14,3 \%$ & $4,2 \%$ & & \\
\hline & Güneş & 4 & $11,4 \%$ & $3,4 \%$ & & \\
\hline & Geri dönüşüm & 3 & $8,6 \%$ & $2,5 \%$ & & \\
\hline & İnek & 1 & $2,9 \%$ & $0,8 \%$ & & \\
\hline \multirow[t]{8}{*}{ Teknoloji } & Binalar & 6 & $35,3 \%$ & $5,0 \%$ & 17 & $14,3 \%$ \\
\hline & Ampul & 2 & $11,8 \%$ & $1,7 \%$ & & \\
\hline & Rüzgâr türbini & 2 & $11,8 \%$ & $1,7 \%$ & & \\
\hline & Fabrika & 2 & $11,8 \%$ & $1,7 \%$ & & \\
\hline & Bilgisayar & 2 & $11,8 \%$ & $1,7 \%$ & & \\
\hline & Kablo & 1 & $5,9 \%$ & $0,8 \%$ & & \\
\hline & Geri dönüşüm & 1 & $5,9 \%$ & $0,8 \%$ & & \\
\hline & Tekerlekler & 1 & $5,9 \%$ & $0,8 \%$ & & \\
\hline Sosyal & İnsan & 11 & $100,0 \%$ & $9,2 \%$ & 11 & $9,2 \%$ \\
\hline \multirow[t]{3}{*}{ Diğer } & Kitap kapağı & 5 & $50,0 \%$ & $4,2 \%$ & 10 & $8,4 \%$ \\
\hline & $\mathrm{El}$ & 4 & $40,0 \%$ & $3,4 \%$ & & \\
\hline & Merdivenler & 1 & $10,0 \%$ & $0,8 \%$ & & \\
\hline \multirow[t]{6}{*}{ Medya } & Çizim & 18 & $39,1 \%$ & $15,1 \%$ & 46 & $38,7 \%$ \\
\hline & Metin & 14 & $30,4 \%$ & $11,8 \%$ & & \\
\hline & Şema & 7 & $15,2 \%$ & $5,9 \%$ & & \\
\hline & Logo & 4 & $8,7 \%$ & $3,4 \%$ & & \\
\hline & Resim & 2 & $4,3 \%$ & $1,7 \%$ & & \\
\hline & Grafik & 1 & $2,2 \%$ & $0,8 \%$ & & \\
\hline Toplam & & 119 & & $100,0 \%$ & 119 & $100,0 \%$ \\
\hline
\end{tabular}

\subsection{Urduca}

Urducada rastlanan görsellerin yaklaşık yarısı medya temasındadır (Tablo 14). Bunu \%31 ile sosyal teması takip etmektedir. Teknolojiye ait hiçbir görsele rastlanılmaması ise ilgi çekicidir.

En çok görsel içeren temalardan biri olan sosyal teması daha çok kadın ve insan görsellerinden oluşmaktadır. Bunun dışında bu dilde elde edilen resimlerde büyük ölçüde görsellere rastlanmaktadır. Bunun dışında kalan görseller ise ancak çok düşük frekanslara sahiptirler. 
Tablo 14. Urduca tema sonuçları

\begin{tabular}{|c|c|c|c|c|c|c|}
\hline \multirow[b]{3}{*}{ Tema } & \multirow[b]{3}{*}{ Alt Tema } & \multicolumn{3}{|c|}{ Alt Tema } & \multirow{2}{*}{\multicolumn{2}{|c|}{ Tema }} \\
\hline & & \multicolumn{3}{|c|}{ Tema İçinde Toplamda } & & \\
\hline & & $n$ & $\%$ & $\%$ & \multicolumn{2}{|r|}{$\%$} \\
\hline \multirow[t]{3}{*}{ Çevre } & Geri dönüşüm & 2 & $50,0 \%$ & $3,6 \%$ & \multirow[t]{3}{*}{4} & \multirow[t]{3}{*}{$7,3 \%$} \\
\hline & Ăgaç & 1 & $25,0 \%$ & $1,8 \%$ & & \\
\hline & Dünya & 1 & $25,0 \%$ & $1,8 \%$ & & \\
\hline \multicolumn{2}{|c|}{ Teknoloji Teknoloji } & 0 & $0,0 \%$ & $0,0 \%$ & 0 & $0,0 \%$ \\
\hline \multirow[t]{2}{*}{ Sosyal } & Kadın & 5 & $29,4 \%$ & $9,1 \%$ & \multirow[t]{2}{*}{17} & \multirow[t]{2}{*}{$30,9 \%$} \\
\hline & İnsan & 12 & $70,6 \%$ & $21,8 \%$ & & \\
\hline \multirow[t]{5}{*}{ Diğer } & Konferans içeriği & 2 & $33,3 \%$ & $3,6 \%$ & \multirow[t]{5}{*}{6} & \multirow[t]{5}{*}{$10,9 \%$} \\
\hline & Mücevher & 1 & $16,7 \%$ & $1,8 \%$ & & \\
\hline & Kitap kapağ 1 & 1 & $16,7 \%$ & $1,8 \%$ & & \\
\hline & İki bardak su (kirli ve temiz) & 1 & $16,7 \%$ & $1,8 \%$ & & \\
\hline & Dolar & 1 & $16,7 \%$ & $1,8 \%$ & & \\
\hline \multirow[t]{4}{*}{ Medya } & Grafik & 22 & $78,6 \%$ & $40,0 \%$ & \multirow[t]{4}{*}{28} & \multirow[t]{4}{*}{$50,9 \%$} \\
\hline & Metin & 4 & $14,3 \%$ & $7,3 \%$ & & \\
\hline & Çizim & 1 & $3,6 \%$ & $1,8 \%$ & & \\
\hline & Logo & 1 & $3,6 \%$ & $1,8 \%$ & & \\
\hline \multicolumn{2}{|l|}{ Toplam } & \multicolumn{2}{|l|}{55} & $100,0 \%$ & \multicolumn{2}{|c|}{$55100,0 \%$} \\
\hline
\end{tabular}

\section{Sonuç}

Bu çalışmada yalnızca içerik analizi yapılmış, görsellerin kullanıldıkları bağlam ele alınmamıştır. Görselleri, kullanıldıkları bağlamda (kullanılan resimle neyin anlatılmak istendiği) anlam analizine tabi tutacak bir çalışmanın yapılması literatüre katkı sağlayacaktır.

Veriler genel olarak değerlendirildiğinde, \%40'lık medya temasından sonra en dikkat çekici oran \%16 ile çevre temasıdır. Bu durum, kurumsal sürdürülebilirlik kavramının tarihsel gelişim sürecinde de gözlenmektedir. Şöyle ki, sürdürülebilirlik kavramını ormanların ekonomik kullanımıyla ilgili kuralları anlatmak amacıyla ve çevresel bir yaklaşım olarak ilk kez kullanan Carl Von Carlowitz (1713)'den günümüze sürdürülebilir kalkınmanın temelde çevresel bir yaklaşım olarak geliştiği görülmüştür. Kavramın süreç içindeki gelişimi ekonomik ve sosyal konuları da kapsayarak, nesiller içi ve nesiller arası ihtiyaçları da dengeleyecek kalkınma modelleriyle geliştirilmiştir (Matiasek 2010: 27). Sürdürülebilirliğin sosyal ve ekonomik boyutlarından daha çok çevresel boyutunun dikkat çekmesini Sanayi Devrimi ile üretimde meydana gelen artışın doğal kaynakların aşırı tüketimi ile doğal ortam dengesinin bozulmasına neden olmasıyla ilişkilendirmek mümkündür. 
Çevre, teknoloji, sosyal ve medya şeklinde sınıflandırmaya tabi tutulan görsellerin genel olarak kapsamı incelendiğinde; çevre temasında yeşil rengin tüm dillerde hâkim olduğu ve doğayı temsilen yaprak, çimen ve ağaç görsellerinin sıklıkla kullanıldığı görülmektedir. Teknolojik içerikte, enerjiyi temsilen ampul ve rüzgâr tribünlerine sıklıkla yer verilmiştir. Yoğunlukla insan, şehir ve ev görselleri sosyal temayı oluşturmaktadır. Şirket logoları ise medyada dikkat çekmektedir. Ayrıca el sembolü (care) koruma, bakma, ilgilenme anlamında sıklıkla dünya ile birlikte kullanılmıştır.

$\mathrm{Bu}$ çalışmanın en önemli sonucu ülkelere ve kültürlere göre kurumsal sürdürülebilirlik algısının değiştiği gerçeğini ortaya koymasıdır. İngilizcenin yoğun olarak kullanıldığı ülkelerin kültürleri, sosyoekonomik yapıları kültürel, ekonomik eğitim vb. oldukça farklıdır. En çok konuşulan diller listemizde ele alınan birçok dil için aynı şey söylenebilir. Tablolar incelendiğinde bu kültürel ayrışmanın görsellerin kullanımında da kendini gösterdiği görülmektedir. Bu ayrışmanın bir kanıtı görsel kullanım miktarları ile ilgilidir. Tablo 2 incelendiğinde İspanyolca, Portekizce, Türkçe ve İngilizce dillerinde bulunan görsel bileşenlerin sayısının Fransızca, Japonca, Rusça ve Urducaya göre neredeyse iki kattır. Bu dilleri kullanan kültürler yazı/şemadan çok kurumsal sürdürülebilirlik kavramını görseller ile anlatmayı tercih etmişlerdir. Yine bu dillerde çevre ile ilgili çok sayıda görsel bileşen bulunurken Japonca, Rusça ve Urducada çevre ile ilgili görsel bileşenler yok denecek kadar azdır. Benzer durum teknoloji içinde geçerli iken sosyal tema ile ilgili görsellerde bu farklılık azalmaktadır.

Tarama sonucunda sinıflandırılan görsellerin analizinde, kurumsal sürdürülebilirliğe yüklenen anlamın dillere göre farklılık gösterdiği tespit edilmiştir. Örneğin, bazı dillerin sınıflandırmasında (İngilizce, İspanyolca, Portekizce) kurumsal sürdürülebilirliğe çevresel boyutuyla yaklaşan görsellere yoğunlukla rastlanırken; birkaç dilin (Bengalce, Urduca, Çince) sınıflandırmasında ise kurumsal sürdürülebilirliğe sosyal boyutuyla yaklaşılmış, insan ve toplumsal görseller odak noktası yapılmıştır. Özellikle daha çok teknolojik gelişimini tamamlamış ve belli bir refah seviyesine ulaşmış ülkelerde konuşulan dillerde teknolojinin çevre üzerindeki etkisi ile ilgili bir farkındalığın oluştuğu gözlenirken; teknolojisi daha az gelişmiş ülkelerde kullanılan dillerde ise insan faktörünün daha fazla öne çıktığını görmek mümkündür.

Teknoloji teması ele alındığında sırası ile Portekizce, Türkçe ve İspanyolca dillerinde açık farkla bir yükseklik gözükmektedir. Bu dillerde teknoloji ile ilgili görseller oldukça fazladır. Fransızca, Urduca, Almanca ve Çince dillerinde ise teknoloji ile ilgili 
görseller yok denecek kadar azdır. Bunların dışında kalan dillerde ise yoğun olmamakla birlikte bazı teknoloji ile ilgili görsellere rastlanmaktadır.

Sosyal temasında en çok görsel Bengalce, Çince ve Urduca dillerinde kullanılmıştır. Her üç dilinde daha çok uzak doğuda yer alan ülkelerde yoğun olarak kullanıldığı hatırlanmalıdır. Bengalce ve Çincede sosyal tema ile ilgili görsel bileşenler (genellikle insan) diğer dillere göre daha fazladır. Ayrıca Bengalce ve Urducanın konuşulduğu ülkelerin henüz teknolojik gelişimlerini tamamlamamış sosyoekonomik düzeylerinin düşük olduğunu belirtmek yerinde olacaktır. Fransızca, Almanca ve Rusça dillerinde ise bu temada çok az sayıda görsele rastlanılmıştır. Diğer ülkelerde sosyal teması altında yer alan görseller orta düzeyde frekanslara sahiptirler.

Medya açısından en çok görsel içeren diller Fransızca, Türkçe, Rusça ve Almancadır. Bunların dışında yer alan ülkeler birbirlerine yakın sayıda görsel içermekle beraber en düşük frekansa sahip diller sırası ile İspanyolca, Urduca ve Bengalce gelmektedir.

Analizlerde dikkat çekici bir başka nokta ise, kurumsal sürdürülebilirlik yaklaşımının gelişimine katkıda bulunan kavramlardan biri olan kurumsal sosyal sorumluluğa yönelik pek çok görselin (şirket logoları, ödül törenleri, faaliyet raporları vb.) yer almasıdır. Montiel (2008: 246) farklı geçmişlere sahip olan bu iki kavramın ortak bir geleceğe doğru ilerlediğini ayrıca, sosyal ve çevresel konuları ekonomik sorumluluklarla dengeleyen bir vizyonu paylaştıklarını belirtmiştir. Van Marrewijk (2003: 102) de kurumsal sürdürülebilirlik ve kurumsal sosyal sorumluluğun benzer, ancak aralarında birkaç küçük farklılığın olduğunu belirtmiştir. Bu nedenle kurumsal sosyal sorumluluk ve kurumsal sürdürülebilirlik görsellerinin iç içe geçmesi olası görülmektedir. Kurumsal sosyal sorumluluk daha çok finansal olmayan toplumsal faaliyetlere yoğunlaşırken; kurumsal sürdürülebilirlik, işletmelerin çevre üzerindeki etkileri ve çevresel faktörlerin işletme üzerindeki etkilerine yoğunlaşmaktadır (Pirnea, Olaru ve Moisa 2011: 39).

Bu çalışma bizlere hem global anlamda "kurumsal sürdürülebilirlik" kavramının nasıl algılandığı ile ilgili ipuçları vermekte, hem de farklı dilleri kullanan toplumların bir tek kavrama ne kadar farklı bakış açıları ile yaklaştığını göstermektedir. Özellikle ekonomik olarak gelişmiş toplumlarda yoğunlukla kullanılan dillerde çevre ile ilgili görsellerin yoğun olduğu gözlenirken; henüz gelişimini tamamlayamamış ülkelerde kullanılan dillerde ise insan faktörünün öne çıktığı görülmektedir. Son olarak Türkçe ile 
yapılan taramayla elde edilen görsellerin daha çok batılı dillerde rastlanılan görseller ile hem oran hem de içerik anlamında benzerlikler gösterdiğini belirtmek gerekir.

\section{Kaynakça}

AUSTIN, Peter (2006). "Survival of languages", Twentyfirst Annual Darwin College Lecture Series 2006: Survival, Lecture 3: 3 February 2006, London: School of Oriental and African Studies.

BANSAL, Pratima (2005). "Evolving sustainably: A longitudinal study of corporate sustainable development", Strategic Management Journal, 26(3): 197-218.

BENN, Suzanne, DUNPHY, Dexter ve GRIFFITHS, Andrew (2006). "Enabling change for corporate sustainability: An integrated perspective", Australasian Journal of Environmental Management, 13(3): 156-165.

DYLLICK, Thomas ve HOCKERTS, Kai (2002). "Beyond the business case for corporate sustainability", Business Strategy and the Environment, 11(2): 130-141.

ETHNOLOGUE (2016). "Summary by language size", Erişim Tarihi: (https://www.ethnologue.com/statistics/size).

FIGGE, Frank ve HAHN, Tobias (2012). "Is green and profitable sustainable? Assessing the trade-off between economic and environmental aspects", International Journal of Production Economics, 140(1): 92-102.

GANESCU, Mariana Cristina (2012). "Corporate social responsibility, a strategy to create and consolidate sustainable businesses", Theoretical and Applied Economics, 19(11): 91-106.

LEE, Ki-Hoon ve BALL, Robert (2003). "Achieving sustainable corporate competitiveness: Strategic link between top management's (green) commitment and corporate environmental strategy", Greener Management International, Winter(44): 89104.

MATIASEK, R. (2010). Corporate sustainability: Company strategies and consumers, (Yayımlanmamış Doktora Tezi), University of Graz, Graz, Austria.

MOLINA-AZORÍN, José F., CLAVER-CORTÉS, Enrique, LÓPEZ-GAMERO, Maria D. ve TARÍ, Juan J. (2009). "Green management and financial performance: A literature review", Management Decision, 47(7): 1080-1100. 
MONTIEL, Ivan (2008). "Corporate social responsibility and corporate sustainability: Separate pasts, common futures", Organization \& Environment, 21(3): 245-269.

PIRNEA, Ionela Carmen, OLARU, Marieta ve MOISA, Cristina (2011). "Relationship between corporate social responsibility and social sustainability", Economy Transdisciplinarity Cognition, 14(1): 36-43.

SCHALTEGGER, Stefan, HERZIG, Christian, KLEIBER, Oliver ve MÜLLER, Jan (2002). Sustainability management in business enterprises: Concepts and instruments for sustainable organisation development (3935630182), Bonn, The Federal Ministry for the Environment, Nature conservation and Nuclear Safety (BMU), Division for Environment and Economy: http://www2.leuphana.de/umanagement/csm/content/nama/downloads/pdfdateien/nmu_fs_engl_final.pdf.

SCHALTEGGER, Stefan, WINDOLPH, Sarah Elena, HARMS, Dorli ve HÖRISCH, Jacob (ed.) (2014). Corporate sustainability in international comparison: State of practice, opportunities and challenges, Cham: Springer International Publishing.

SHARMA, Sanjay ve RUUD, Audun (2003). "On the path to sustainability: Integrating social dimensions into the research and practice of environmental management", Business Strategy and the Environment, 12(4): 205-214.

SHRIVASTAVA, Paul ve HART, Stuart (1995). "Creating sustainable corporations", Business Strategy and the Environment, 4(3): 154-165.

VAN MARREWIJK, Marcel (2003). "Concepts and definitions of CSR and corporate sustainability: Between agency and communion", Journal of Business Ethics, 44(2-3): 95-105.

WAGNER, Marcus ve SCHALTEGGER, Stefan (2004). "The effect of corporate environmental strategy choice and environmental performance on competitiveness and economic performance: An empirical study of EU manufacturing", European Management Journal, 22(5): 557-572.

WEBER, George (1997). "Top languages: The world's 10 most influential languages", AATF National Bulletin, 24(3): 22-28.

ZHANG, Feng, RIO, Maud, ALLAIS, Romain, ZWOLINSKI, Peggy, CARRILLO, Tatiana Reyes, ROUCOULES, Lionel, MERCIER-LAURENT, Eunika ve 
Mustafa Nuri URAL, Özlem TUNA, "Kurumsal Sürdürülebilirliğin Dünyanın En Çok Konuşulan Dillerinde Çevrimiçi Görsel Algısı", Mavi Atlas, 7(2)/2019: 220-242

BUCLET, Nicolas (2013). "Toward an systemic navigation framework to integrate sustainable development into the company", Journal of Cleaner Production, 54: 199-214. 